\title{
Profile Performance of Working Memory in Children of Elementary Schools
}

\author{
Rita de Cássia Coutinho Vieira Fornasari, Taís de Lima Ferreira, Sylvia Maria Ciasca \\ Department of Neurology, Research Laboratory of Learning and Attention Disorders (DISAPRE), School of \\ Medical Sciences, State University of Campinas (UNICAMP) Campinas, São Paulo, Brazil \\ Email: rita.fornasari@uol.com.br
}

Received July 25 ${ }^{\text {th }}$, 2013; revised August $28^{\text {th }}$, 2013; accepted September $27^{\text {th }}, 2013$

Copyright (C 2013 Rita de Cássia Coutinho Vieira Fornasari et al. This is an open access article distributed under the Creative Commons Attribution License, which permits unrestricted use, distribution, and reproduction in any medium, provided the original work is properly cited.

\begin{abstract}
Objective: To compare the performance of working memory in children of 5 years and 1 month to 6 years and 11 months of public and private Elementary Schools. Methods: 34 subjects were evaluated for both genders composing the GI and GIII public education aged 5 - 6 years; GII and GIV private education aged 5 - 6 years, with an average age of 6 years and 11 months. All subjects were submitted to the Working Memory Assessment Protocol. Results: There were statistically significant differences between the public school and private school in tests of verbal span of serial repetition in direct order with words like phonology and semantics and different words with different semantics and phonology. Between groups, a statistically significant difference occurred between GIII and GIV in verbal span, free recall for polysyllabic words with different semantics and complex phonology; between GI and GII, GIII and GII, GIII and GIV, the verbal span of words with phonology and different semantics, and between GIII and GIV in verbal span of words with the same phonology and semantics. The variables in these groups are age and type of school. Conclusion: With advancing age and grades, the developments of working memory and best performance of working memory were for public school children aged 6 years.
\end{abstract}

Keywords: Working Memory; Language; Children; Elementary School

\section{Introduction}

The literacy process involves the phonological structure of oral language, the conceptual organization, lexical representation and working memory, which accesses and retrieves the graphical representations related to speech sounds (Mezzomo \& Mota Dias, 2010).

Working memory whose function is to maintain, for a short period of time, the information that is being processed, and it leaves no traces and does not produce files (Baddeley, Andersen, \& Eysenck, 2011) consisting of the conscious representation and temporal manipulation of the information necessary to perform complex cognitive operations such as learning, language comprehension and reasoning (Morgado, 2005).

The model of Baddeley (2000) suggests that working memory is a system composed of four components. The central executive handles tasks of higher cognitive demand and has four functions: to coordinate performance on two tasks (e.g., simultaneously store and process information), choose a task, strategy or operation; attend to relevant information and inhibit irrelevant information, and enable and retrieve long-term memory (Anderson \& Lyxell, 2007).

The phonological component (phonological loop) keeps the information verbally coded for a short period of time and refeeding it through a subcomponent, the Articulatory loop (Baddeley \& Hitch, 1974; Bueno \& Oliveira, 2004).

The visual-spatial sketchpad performs the processing and maintenance of visual and spatial information related to the objects and spatial relationships between them. At the same time, it plays an important role in the formation and manipulation of mental images (Baddeley, 2006).

A fourth component recently included the model and the Episodic Buffer acted as a retainer responsible for the integration of information from the phonological loop and the visuo-spatial layout information from long-term memory (Baddeley, 2000).

During childhood, the phonological component of working memory develops and is linked to the development of language, being observed in everyday speech and the child's vocabulary that increase in size and complexity, thus underlining the role that memory on language in their semantic and pragmatic aspects (Scheuer, 2009).

For acquisition and phonological development, the child makes use of perception, production and organization of the rules, i.e. the child to acquire the phoneme, also learns its distribution in syllables and words (Lamprecht, 2004).

Up to 6 years, it is expected that the child has established a complete inventory phonological (Wertzner, Amaro, \& Galea, 2007).

Mota-SoaresKeske and Linassi (2004) argue that changes in phonological working memory can have flaws in the organization and production of speech sounds and it has been associated with phonological disorders and speech and language.

Rodrigues and Befi-Lopes (2009) described and analyzed the relationship between phonological working memory and language development in children with normal language development. The resulting figure shows the relationship between lexi- 
cal and phonological structure and phonological working memory in children with normal development. Lobo, Acrani and Avila (2008) state that the evaluation of the performance of phonological working memory may provide us relevant data on language ability and language development of children with and without communication disorders. This study aimed to compare the performance of working memory among children 5 years and 6 years of public and private elementary school.

\section{Method}

\section{Context}

The research was conducted inpreschool and elementary schools (1st year) from the city of Capivari, state of São Paulo, Brazil namely: Colegio EAC-Kindergarten and Elementary Education-private, EMEI Professor Lenita Camargo Figueiredo and EEF José Benedito P. Antunes, both public schools.

\section{Participants}

With the approval of the Research Ethics Committee (REC) of the School of Medical Sciences, No. 08088112.4.0000.5404, participated in this study 34 subjects aged 5 - 6 years, of both genders, students from preschool and 1st grade of public and private education in the city of Capivari, state of São Paulo, Brazil, divided into 4 groups: GI (5 yrs $1 \mathrm{mth}$ to 5 yrs $11 \mathrm{mths}$ ) and GIII (6 yrs 1 mth to 6 yrs 11 mths) from the public, GII (5 yrs $1 \mathrm{mth}$ to 5 yrs $11 \mathrm{mths}$ ) and GIV (6 yrs $1 \mathrm{mth}$ to 6 yrs 11 mths) in private.

For the formation of groups was performed speech screening with parents and/or guardians to clarify questions about the development and overall health of the child and the designation, made by teachers, good students without learning disabilities and attention.

Inclusion criteria for the choice of research subjects were signatures of the term of free and informed consent (IC); subjects aged five to six years; provide speech and language development within the normal range, and subjects who did not complaints of visual and auditory acuity.

Were excluded from the study subjects presented: speech complaints, such as language delay, articulation disorders and phonological and/or phonetic; complaints of inattention; attend or have attended speech therapy, and parents or guardians did not authorize participation in research.

\section{Materials}

For the evaluation of the subjects using the Working Memory Protocol Assessment (WMPA) (Ferreira, 2011). This protocol evaluates auditory skills performance tests in serial repetition in direct order, evidence of free recall and verbal span tests. Proofs of serial repetition have alternation between the number of syllables of words and how to semantics and phonology of the same, being linguistically balanced according to the complexity of speech articulation, word length and degree of familiarity of the words in the English language. The visual ability is assessed with tests of visual span in the forward and reverse order. This protocol has a total of 6 trials, 5 trials subdivided into up to 5 items. The time of application of the Protocol was around 20 minutes.

\section{Procedures}

In the performance of the Working Memory Protocol Assessment (Ferreira, 2011) the evidence of auditory memory were applied orally, in which the researcher guided the subject to hear the order given and repeat according to the variations of each test and subtest. In the visual memory tests, the subjects were given colored cards, in which the researcher asked the subjects to visualize the order presented, and they should play in the forward and in reverse order. The maximum score of this test is 144 points to be obtained in the correct performance of $100 \%$ of the words.

\section{Data Analysis}

For this study was performed by descriptive and inferential statistics using SPSS for Windows (version 20.0). Descriptive analyzes were performed to characterize the groups and inferential analyzes to compare the performance between the groups (Fisher's Exact Test, Kruskal-Wallis and Mann Whitney), considered the significance level of 5\%, i.e., $p<0.05$.

The Mann-Whitney aims to investigate possible differences in working memory performance between groups.

The Kruskal-Wallis nonparametric test is used to compare three or more independent samples, indicating whether there is a difference between at least two of them.

Fischer's Exact Test comparing small samples in two independent groups and determines the exact probability of occurrence of an observed frequency.

The results indicate that statistically significant differences are marked in bold and asterisk $(*)$.

In this study, we used a significance level of $5 \%(0.05)$, i.e., when the calculated significance value (p) is less than $5 \%$, meaning that the difference or relationship is statistically significant, and when the value calculated significance (p) is equal to or greater than $5 \%$, meaning that the ratio or difference is not statistically significant.

\section{Applied Tests}

To better understand the following tables the names of each test and subtest were transformed into acronyms applied as shown in the table below (Figure 1).

\section{Results}

\section{Characterization of Groups}

This study was conducted with the participation of 34 subjects divided into four groups, with group GI consists of 8 subjects of both sexes with ages ranging from 5 years and 1 month to 5 years and 11 months from the public school the GII consists of 8 subjects of both sexes with ages ranging from 5 years and 1 month to 5 years and 11 months from the private schools, the GIII group consisting of 9 subjects of both sexes with age ranging from 6 years and 1 month to 6 years and 11 months from the public school system and GIV group consisting of 9 subjects of both sexes with ages ranging from 6 years and 1 month to 6 years and 11 months from private schools.

Table 1 presents the frequency of the number of subjects in each group per grade, and GIII and GIV a higher number of subjects.

The average age among the subjects in grades is shown in 


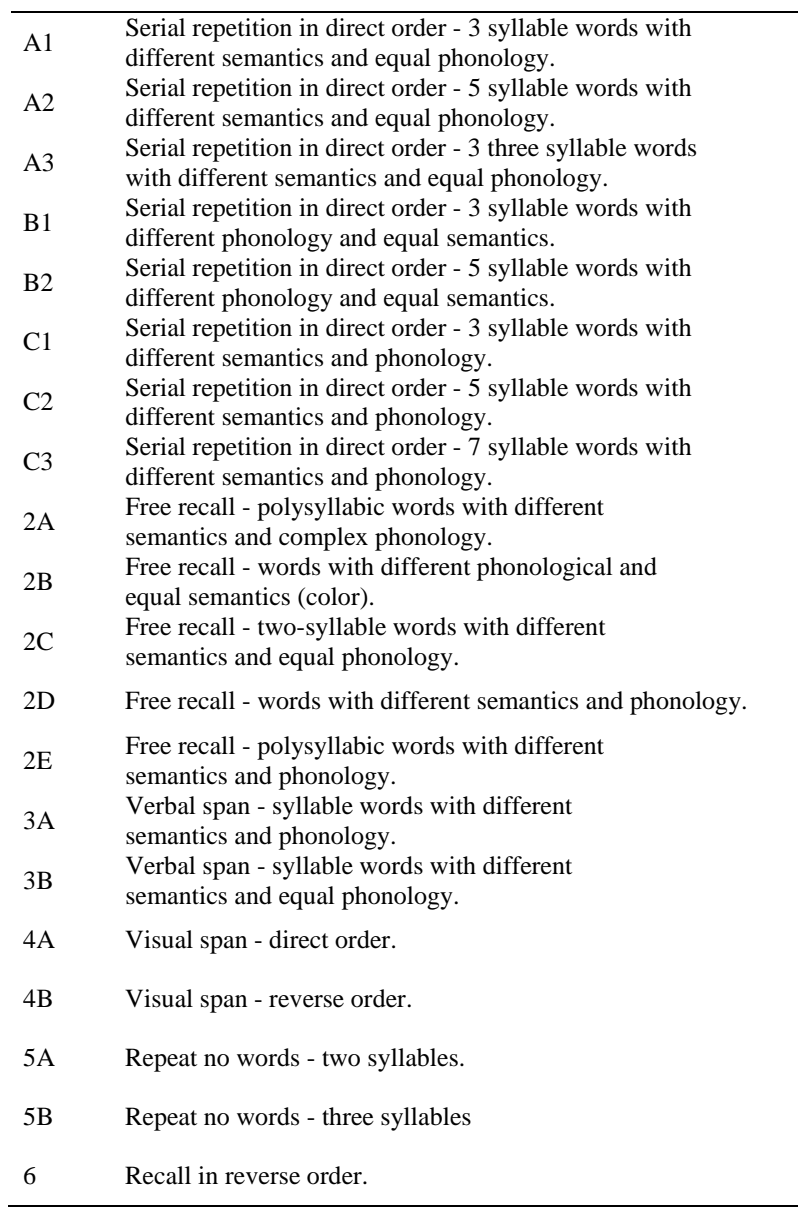

Figure 1.

Abbreviation of the subtests of the evaluation protocol of working memory.

Table 1.

Frequency of subjects per group and grade.

\begin{tabular}{ccccc}
\hline & \multicolumn{3}{c}{ Grade } & Total \\
\hline \multirow{2}{*}{ G I } & $f$ & Pre-School & First Year \\
& $\%$ & 50 & 0 & 8 \\
G II & $f$ & 8 & 0 & 24 \\
& $\%$ & 50 & 0 & 8 \\
G III & $f$ & 0 & 0 & 24 \\
& $\%$ & 0 & 9 & 9 \\
G IV & $f$ & 0 & 50 & 26 \\
& $\%$ & 0 & 9 & 9 \\
Total & $f$ & 16 & 50 & 26 \\
& $\%$ & 100 & 18 & 34 \\
\hline
\end{tabular}

Notes: (f) frequency, (\%) percentage; (GI) Public School: 5.1 - 5.11 years; (GII) Private School: 5.1 - 5.11 years; (GIII) Public School: 6.1 - 6.11 years; (GIV) Private School : 6.1 - 6.11 years.
Table 2, which is 6.11 years in pre-school and first year ( $p=$ 0.00 ), analysis of the Mann-Whitney test.

Table 3 shows the performance of working memory among groups. Note statistically significant difference in the subtest (A2) of serial repetition in direct order for five syllable words with equal phonology and semantics different $\left(p<0.02^{*}\right)$, in the verbal span test (3A) of two-syllable words with phonology and different Semantics $\left(p<0.00^{*}\right)$ and the verbal span (3B) for two-syllable words with the same phonology and different semantics $\left(p<0.02^{*}\right)$. In the other tests and subtests, there were no statistically significant differences between schools.

Table 2.

Comparison between the age and grade.

\begin{tabular}{cccc}
\hline Grade & Average & $N$ & $S D$ \\
\hline Pre-School & 5.64 & 16 & 0.26 \\
First Year & 6.53 & 18 & 0.31 \\
Total & 6.11 & 34 & 0.53 \\
\hline
\end{tabular}

Notes: (N) no. of subjects; (SD) Standard Deviation, $\mathrm{p}=0.00$, Mann-Whitney test.

Table 3.

Comparison of working memory among schools.

\begin{tabular}{|c|c|c|c|c|c|}
\hline \multicolumn{5}{|c|}{ Schools } & \multirow[b]{3}{*}{ p-value } \\
\hline & \multicolumn{2}{|c|}{ Public } & \multicolumn{2}{|c|}{ Private } & \\
\hline Test & A & $S D$ & A & $S D$ & \\
\hline A1 & 2.68 & 0.50 & 2.32 & 0.81 & 0.13 \\
\hline A2 & 1.56 & 0.30 & 1.26 & 0.36 & $0.02 *$ \\
\hline A3 & 1.91 & 0.57 & 1.53 & 0.84 & 0.22 \\
\hline B1 & 3.00 & 0.00 & 2.94 & 0.24 & 0.32 \\
\hline B2 & 1.74 & 0.75 & 1.76 & 0.59 & 0.96 \\
\hline C1 & 2.53 & 0.74 & 2.06 & 0.91 & 0.12 \\
\hline C2 & 1.32 & 0.77 & 0.79 & 0.64 & 0.05 \\
\hline C3 & 0.03 & 0.12 & 0.06 & 0.17 & 0.55 \\
\hline $2 \mathrm{~A}$ & 2.35 & 0.86 & 1.76 & 0.97 & 0.06 \\
\hline $2 \mathrm{~B}$ & 4.06 & 1.52 & 3.12 & 1.50 & 0.09 \\
\hline $2 \mathrm{C}$ & 2.65 & 1.06 & 2.29 & 0.92 & 0.30 \\
\hline $2 \mathrm{D}$ & 2.59 & 1.12 & 2.06 & 1.14 & 0.14 \\
\hline $2 \mathrm{E}$ & 2.29 & 0.92 & 2.35 & 1.46 & 0.99 \\
\hline $3 \mathrm{~A}$ & 3.65 & 0.61 & 2.71 & 0.85 & $0.00^{*}$ \\
\hline 3B & 3.18 & 0.64 & 2.53 & 0.80 & $0.02^{*}$ \\
\hline $4 \mathrm{~A}$ & 3.65 & 1.00 & 3.59 & 1.12 & 0.84 \\
\hline 4B & 2.76 & 1.09 & 2.82 & 1.07 & 0.79 \\
\hline $5 \mathrm{~A}$ & 1.47 & 1.07 & 1.65 & 0.93 & 0.55 \\
\hline $5 \mathrm{~B}$ & 1.76 & 0.75 & 1.29 & 0.92 & 0.09 \\
\hline 6 & 1.82 & 0.88 & 2.18 & 1.24 & 0.53 \\
\hline Total & 47.00 & 7.56 & 41.12 & 8.38 & 0.05 \\
\hline
\end{tabular}

Notes: (A) Average, (SD) Standard Deviation; $\left(^{*}\right)$ Statistically significant difference $(p<.05)$. 
Table 4 shows the comparison of the performance of working memory among groups. Table 5, $p<0.05$, shows statistically significant results for the test of free recall of two-syllable words with different semantics and complex phonology (2A), resulting in a statistically significant difference in GIII and GIV $\left(p=0.01^{*}\right)$, the subtest (3A) of the verbal span for two-syllable words with different semantics and phonology resulting statistically significant difference in GI and GII ( $\left.p=0.03^{*}\right)$, GIII and GIV groups $\left(p=0.04^{*}\right)$ and in GII and GIII $\left(p=0.04^{*}\right)$, this group is no different between the ages, in the subtest (3B) of the verbal span for two-syllable words with different semantics and phonology equal no statistically significant difference in GIII and GIV $\left(p=0.02^{*}\right)$. In the other tests and subtests is no significant difference between groups.

\section{Discussion}

The development of children's oral language and communication are related to the development of working memory, as

Table 4.

Comparison of working memory among groups.

\begin{tabular}{|c|c|c|c|c|c|c|c|c|}
\hline \multirow[b]{3}{*}{ Test } & \multicolumn{8}{|c|}{ Groups } \\
\hline & \multicolumn{2}{|c|}{ GI } & \multicolumn{2}{|c|}{ GII } & \multicolumn{2}{|c|}{ GIII } & \multicolumn{2}{|c|}{ GIV } \\
\hline & A & $S D$ & A & $S D$ & A & $S D$ & A & $S D$ \\
\hline $\mathrm{A} 1$ & 2.62 & 0.44 & 2.31 & 1.00 & 2.72 & 0.57 & 2.33 & 0.66 \\
\hline A2 & 1.50 & 0.27 & 1.38 & 0.35 & 1.61 & 0.33 & 1.17 & 0.35 \\
\hline A3 & 2.06 & 0.68 & 1.25 & 1.04 & 1.78 & 0.44 & 1.78 & 0.57 \\
\hline B1 & 3.00 & 0.00 & 2.87 & 0.35 & 3.00 & 0.00 & 3.00 & 0.00 \\
\hline B2 & 1.31 & 0.70 & 1.69 & 0.70 & 2.11 & 0.60 & 1.83 & 0.50 \\
\hline C1 & 2.25 & 0.96 & 1.88 & 1.09 & 2.78 & 0.36 & 2.28 & 0.71 \\
\hline C2 & 1.25 & 0.65 & 0.75 & 0.65 & 1.39 & 0.89 & 0.83 & 0.66 \\
\hline C3 & 0.06 & 0.18 & 0.06 & 0.18 & 0.00 & 0.00 & 0.06 & 0.17 \\
\hline $2 \mathrm{~A}$ & 2.25 & 1.04 & 2.25 & 1.04 & 2.44 & 0.73 & 1.33 & 0.71 \\
\hline $2 \mathrm{~B}$ & 4.00 & 1.69 & 3.38 & 1.30 & 4.11 & 1.45 & 2.89 & 1.69 \\
\hline $2 \mathrm{C}$ & 2.50 & 0.93 & 2.38 & 0.74 & 2.78 & 1.20 & 2.22 & 1.09 \\
\hline $2 \mathrm{D}$ & 2.50 & 1.20 & 2.00 & 1.41 & 2.67 & 1.12 & 2.11 & 0.93 \\
\hline $2 E$ & 2.13 & 0.99 & 2.38 & 1.77 & 2.44 & 0.88 & 2.33 & 1.22 \\
\hline $3 \mathrm{~A}$ & 3.63 & 0.52 & 2.63 & 0.92 & 3.67 & 0.71 & 2.78 & 0.83 \\
\hline 3В & 2.88 & 0.35 & 2.50 & 0.93 & 3.44 & 0.73 & 2.56 & 0.73 \\
\hline $4 \mathrm{~A}$ & 3.38 & 0.92 & 3.87 & 0.99 & 3.89 & 1.05 & 3.33 & 1.22 \\
\hline $4 B$ & 2.50 & 0.93 & 2.63 & 1.19 & 3.00 & 1.22 & 3.00 & 1.00 \\
\hline $5 \mathrm{~A}$ & 1.50 & 1.20 & 1.88 & 0.99 & 1.44 & 1.01 & 1.44 & 0.88 \\
\hline $5 B$ & 1.88 & 0.83 & 1.25 & 0.89 & 1.67 & 0.71 & 1.33 & 1.00 \\
\hline 6 & 1.88 & 0.64 & 1.87 & 1.46 & 1.78 & 1.09 & 2.44 & 1.01 \\
\hline Total & 45.06 & 7.35 & 41.19 & 10.50 & 48.72 & 7.75 & 41.06 & 6.62 \\
\hline
\end{tabular}

Notes: (A) Average, (SD) Standard Deviation.
Table 5.

Comparison of the performance of working memory among groups with $p<0.05$.

\begin{tabular}{|c|c|c|c|c|c|c|c|c|c|}
\hline \multicolumn{10}{|c|}{ Groups } \\
\hline & \multicolumn{2}{|c|}{ GI } & \multicolumn{2}{|c|}{ GII } & \multicolumn{2}{|c|}{ GIII } & \multicolumn{2}{|c|}{ GIV } & \multirow[b]{2}{*}{$p$-value } \\
\hline Test & A & $S D$ & A & $S D$ & A & $S D$ & A & $S D$ & \\
\hline $2 \mathrm{~A}$ & & & & & 2.44 & 0.73 & 1.33 & 0.71 & $0.01 *$ \\
\hline $3 \mathrm{~A}$ & 3.63 & 0.52 & 2.63 & 0.92 & & & & & $0.03^{*}$ \\
\hline $3 \mathrm{~A}$ & & & & & 3.67 & 0.71 & 2.78 & 0.83 & $0.04 *$ \\
\hline $3 \mathrm{~A}$ & & & 2.63 & 0.92 & 3.67 & 0.71 & & & $0.04 *$ \\
\hline 3B & & & & & 3.44 & 0.73 & 2.56 & 0.73 & $0.02 *$ \\
\hline
\end{tabular}

Notes: (A) Average, (SD) Standard Deviation; (*) Statistically significant difference $(p<0.05)$.

this allows the formal and informal learning, acquire new knowledge and integration of information. Thus the language and working memory develop with age (Befi Rodrigues-Lopes, 2009).

The overall results of this study demonstrated better performance of the subjects of public schools for all tests of WMPA (Ferreira, 2011) with data with significant differences between groups GIII and GIV, which are formed by subjects aged 6 years in first grade, with the variable type of school.

The hypothesis raised by the authors, which further supports these results is that the subjects of public schools showed more interest and attention during the implementation of the protocol and the environment of this school was more favorable, with respect to the noise level, compared to private school.

This is corroborated by studies Gindri et al. (2005) stating that the educational process is important for the development of the child, taking into consideration the importance of learning processes in the development of higher mental functions, which explains the better performance in this range age.

In relation to GI and GII, the result was significant for verbal span test, being the age of 5 years subject to the variable type of school, and GI and GII public school private school. In a study of Brazilian children aged 4 - 10 years the authors observed the effects of age, extension, education and lexically, and the length effect was observed with the decrease in the repetition of words with 2 - 5 syllables, all ages. The effect of education was only observed in children from 5 years. This is due to the influence of reading and writing that can make phonological processing and phonological awareness child. (Santos \& Bueno, 2003).

Regarding the type of school a study in Bahia does not corroborate with the finding of this research, it shows that children 3 - 12 years attending public and private schools when they were evaluated in sequential memory of syllables, the results indicated that the Children are capable of repeating 2 of 3 sequences of 3 syllables, children aged 6 years repeated 2 of the sequences of 4 syllables and 9 years old were able to repeat the 3 sequences, concluding that there is progress in the performance of working memory (the respect to phonological loop) according to increasing age (Corona, Pereira, Ferrite, \& Rossi, 2005).

In the study by Ferreira (2011) compared the performance of working memory in children with Attention Deficit Disorder and Hyperactivity Disorder (ADHD) and children without 
complaints learning and attention, 7 - 11 years enrolled in public education, the results concluded that children with ADHD had worse performance on all memory tests compared to children without learning complaints and attention, which may be related to the performance of attention and executive functions, leading to a loss of all cognitive abilities.

Analyzing the data in Table 3, the results show a statistically significant difference in retesting serial two-syllable words with different semantics and phonology equal to public school with an average of 1.56, and in contrast to private school had an average of 1.26. According to a study of Rodrigues and Befi-Lopes (2009) changes the phonological working memory in relation to phonological storage are related to the similarity of the effect of phonological word length, since word sequence are less similar reminded of the word sequences are not similar showing that it is verbal information represented by a specific phonological system rather than another system such as visual or semantics. Andrade (2002) shows that the effect of phonological similarity with words with similar sounds final hinder access to meaning, thus impairing their memory. This research corroborates the result of the study Mousinho, Correa (2009) showed that the school can contribute to the skills of phonological processing, since the children have good oral and assessed a storage system adequate information because they have no changes.

In tests of verbal span for words phonology and equal semantics the results were statistically significant for the public school with an average of 3.65. In contrast to private school had an average $2.71(p=0.00)$, in the verbal span of two-syllable words with different semantics and equal phonology public school had an average 3.18 and private school had an average $2.53(p=0.02)$. These results correlate with the effect of phonological similarity, which has been cited above. Ferreira and Sagrilo (2012) assessed children male and female and observed better performance on verbal span in both genders in the repetition of two-syllable words with different phonology and semantics than in two-syllable words with equal phonology and different semantics. According to Andrade (2002) subjects with ADHD showed better recall of words with semantic similarity, since it compensates for the difficulty caused by phonological similarity and that access to the meaning of each word can also facilitate your recall. These data corroborate the findings of this research in relation to semantic similarity. With regard to schooling there has been previous reference to its importance for the performance of working memory.

Table 5 is a comparison between the groups, which have a variable age and type of school. The results show statistically significant differences in tests of free recall of polysyllabic words with complex phonology and different semantics between GIII and GIV, noting that the age of the subjects is the same for the two groups (six years) and the variable type of school is different. In verbal span test $3 \mathrm{~A}$, the results indicate a statistically significant difference in GI (average 3.63) and GII (average 2.63) with $p=0.03$. The age variable is different in verbal 3A span between GII and GIII, and GIII presents subjects with higher age (6 years) correlating again that age helps the development of language and memory (GINGRICH et al., 2005).

In the test of verbal span 3B, two-syllable words with different semantics and equal phonology, the difference was statisticcally significant between groups GIII (average 3.44) and GIV (average 2.56), $p=0.02$, and the variable type of school.
Other studies correlate the sound information in working memory with school performance, reading level and age. The maturation of working memory skills improved significantly in children from 1st grade compared to children from preschool (GINGRICH et al., 2005, 2007).

The effect of word length, in a study conducted by Rodrigues and Befi-Lopes (2009) shows that the best performance in the repetition of sequences of words whose time articulating to pronounce phonemes, syllables, words or pseudowords is less. This effect would occur because items that are pronounced more quickly are less likely to decline in phonological working memory before your total repetition is performed, easing the process of reverberation. According to Cunha and Capellini (2010) the performance of working memory in children from $1^{\text {st }}$ to $5^{\text {th }}$ grade in public school is better over school grades, influencing the reading. These studies corroborate the findings of this research.

Repeat testing of non-words and visual span showed no statistically significant differences in this study, but several studies have demonstrated the importance of words not in the development of language and working memory. According to Rodrigues and Befi-Lopes (2009), the ability to not words facilitates the acquisition of new vocabulary and sentence comprehension with higher syntactic complexity and working memory allows the acquisition of metalinguistic skills such as grammatical sentences judgment tasks and conscience phonological. Ferreira (2011) in comparative studies of children with ADHD and children without complaints learning and attention shows that the recall tests no words there was no statistically significant difference, but the performance was higher for children without learning. In this type of task the children do not use support semantic or lexical aspects to remember. Probably make use of phonological aspect for memory, suggesting that working memory depend not only attention, but also of phonological processing.

Regarding visual span Barbosa et al (2010) in studies with children from 2nd and 3rd grade of elementary school investigated the relationship between the skills of visual memory and spelling and concluded that the acquisition of spelling rules is related to good memory ability visual.

The recall test in reverse order not statistically significant in this study. According to the study by Ferreira (2011) among children with ADHD and children without complaints learning and attention differences were observed between these groups with better performance for children without learning complaints and attention corroborating Andrade (2002), as is not an everyday task, requiring greater use of attention.

\section{Conclusion}

Data from this study showed that the subjects of the public had superior performance in all tests that assessed working memory compared to subjects in private and that performance was higher for subjects aged 6 years since the school age, and assisted in the development of language and memory.

\section{REFERENCES}

Anderson, U., \& Lyxell, B. (2007). Working memory deficit in children with mathematical difficulties: A general or specific deficit? Journal of Experimental Child Psychology, 96, 197-228. http://dx.doi.org/10.1016/j.jecp.2006.10.001 
Andrade, E. R. (2002). Memória de trabalho verbal e visual em crianças com transtorno do déficit de atenção/hiperatividade. Ph.D. Thesis, São Paulo (SP): Universidade de São Paulo.

Baddeley, A. D. (2000). The episodic buffer: A new component of working memory? Trends in Cognitive Sciences, 4, 417-423. http://dx.doi.org/10.1016/S1364-6613(00)01538-2

Baddeley, A. D., Anderson, M., \& Eysenck, M. (2011). Memória. Porto Alegre: Artmed.

Baddeley, A. D., \& Hitch, G. J. (1974). Working memory. In G. A. Bower (Ed.), Recent advances in learning and motivation. New York: Academic Press.

Baddeley, A. D. (2006). Working memory: An overview. In Working memory and education, Amsterdan: Elsevier Press.

Barbosa, P. M. F., Bernardes, N. G. B., Misorelli, M. I., \& Chiappetta, A. L. M. L. (2010). Relação da memória visual com o desempenho ortográfico de crianças de $2^{\mathrm{a}}$ e $3^{\mathrm{a}}$ séries do ensino fundamental. Revista CEFAC, 12, 598-607. http://dx.doi.org/10.1590/S1516-18462010000400009

Bueno, O. A. (2004). Memória e amnésia. In Neuropsicologia hoje, São Paulo: Artes Médicas.

Corona, A. P., Pereira, L. D., Ferrite, S., \& Rossi, A. G. (2005). Memória sequencial verbal de 3 e 4 sílabas em escolares. Revista PróFono, 17, 27-36.

Cunha, V. L. O., \& Capellini, S. A. (2010). Análise psicolinguística e cognitivo-linguística das provas de habilidades metalinguísticas e leitura realizadas em escolares de $2^{\mathrm{a}}$ a $5^{\mathrm{a}}$ série. Revista CEFAC, 12, 772-783. http://dx.doi.org/10.1590/S1516-18462010005000017

Gindri, G., Keske-Soares. M., \& Mota, H. B. (2005). Comparação do desempenho de crianças pré-escolares e de $1^{\mathrm{a}}$ série em tarefas envolvendo a memória de trabalho. Revista da Sociedade Brasileira de Fonoaudiologia, 10, 201-206.

Gindri, G., Keske-Soares. M., \& Mota, H. B. (2007). Memória de trabalho, consciência fonológica e hipótese de escrita. Revista PróFono, 19, 313-322.

Ferreira, T. L. (2011). A avaliação da memória de trabalho auditiva e visual em crianças com o déficit de atenção e hiperatividade. Thesis, Campinas (SP): Universidade Estadual de Campinas.

Lamprecht, R. R. (2004). Aquisição fonológica do Português: Perfil de desenvolvimento e subsídios para terapia. Porto Alegre (RS): Artmed.

Lobo, F. S., Acrani, O. I., \& Ávila, C. R. B. (2008). Tipo de estímulo e memória de trabalho fonológica. Revista CEFAC,10.

Mezzomo, C. L., Mota, H. B., \& Dias, R. F. (2010). Desvio fonológico: Aspectos sobre a produção, percepção e escrita. Revista Sociedade Brasileira de Fonoaudiologia, 15.

Morgado, I. (2005). Psicologia delaprendizaje y la memoria: Fundamentos y avances recientes.Revista de Neurologia. Barcelona, 40, 289-297.

Mota, H. B., Keske-Soares, M., \& Linassi, L. Z. (2004). Habilidades de memória de trabalho e o grau de severidade do desvio fonológico. Revista Pró-Fono, 1, 75-82.

Mousinho, R., \& Correa, J. (2009). Habilidades linguístico-cognitiva em leitores e não leitores. Revista Pró-Fono, 21, 113-118.

Rodrigues, A., \& Befi-Lopes, D. M. (2009). Memória operacional fonológica e suasrelações com o desenvolvimento da linguagem infantil. Revista Pró-Fono, 21, 63-69.

Sagrilo, M. C. P., \& Ferreira, T. L. (2012). Diferença entre span verbal e visual nos gêneros. Revista CEFAC, 15.

Santos, F. H., \& Bueno, O. F. (2003). Validation of the Brazilian children's test of Pseudowords repetition in Portuguese speakers aged 4 to 10 years. Brazilian Journal of Medical and Biological Research, 36, 1533-1547. http://dx.doi.org/10.1590/S0100-879X2003001100012

Scheuer, C. I. (2005). Memória e linguagem. In L. P. Ferreira, D. M. Befi-Lopes, \& S. C. O. Limongi (Eds.), Tratado de fonoaudiologia (2nd ed.). São Paulo: Roca.

Wertzner, H. F., Amaro, L., \& Galea, D. E. (2007). Phonological Performance measured by speech severity indices compared with correlated factors. São Paulo Medical Journal, 125, 309-314. http://dx.doi.org/10.1590/S1516-31802007000600002 